\title{
Assessment of Contaminated Soil with Some Heavy Metals in Selected Auto Repair Shops in Katsina North Western, Nigeria
}

\author{
Rabe JM1*, Agbaji EB¹, Zakka Y1, Muhammed HM² and Rabe AM³ \\ ${ }^{1}$ Department of Pure and Applied Chemistry, Ahmadu Bello University, Nigeria \\ ${ }^{2}$ Department of Biological Sciences, Ibrahim Badamasi Babangida University, Nigeria \\ ${ }^{3}$ Department of Biological Sciences, Usmanu Danfodiyo University, Nigeria
}

*Corresponding author: Rabe JM, Department of Pure and Applied Chemistry, Ahmadu Bello University, Nigeria; Email: jamynglass@gmail.com

\section{Research Article \\ Volume 1 Issue 2}

Received Date: December 06, 2018

Published Date: December 20, 2018

DOI: $10.23880 /$ oajwx-16000113

\section{Abstract}

Anthropogenic activities of humans lead to heavy metals toxicity into the soils. Auto mechanic workshops are one of the major sources of increase in heavy metal concentration in soils in Katsina North western Nigeria. Katsina is located on latitude $12^{\circ} 59^{\prime} \mathrm{N}$ and longitude $7^{\circ} 36^{\prime} \mathrm{E}$ and it's the capital city of Katsina state Nigeria. Five selected auto repair shops which include; Garejin Tsohuwar Tasha (TT), Albarkar Motors-Garage (AM), Garejin Abdulhadi (GA), Garejin Bebeji (GB) and Garejin KofarDurbi (GK) were considered for this study. Heavy metals in the soil samples at $0-15 \mathrm{~cm}$ and $15-30 \mathrm{~cm}$ depths were subjected to sequential extraction to ascertain the bioavailability of the metals in the soils. The percentage bioavailability of metals in the experimental sites at $0-15 \mathrm{~cm}$ were; (GB- $\mathrm{Cd}-23.08 \%, \mathrm{~Pb}-38.48 \%, \mathrm{Cu}-33.49 \%$, Zn-44.15\%, Cr-23.1\%), (GK-Cd-57.38\%, Pb 65.49\%, Cu-71.59\%, Zn-41.75\%, Cr-57.02\%), (TT-Cd 28.30\%, Pb 31.70\%, Cu26.93\%, Zn-64.47\%, Cr-27.24\%), (AM-Cd 36.59\%, Pb-47.67\%, Cu-25.45\%, Zn-54.26\%, Cr-21.39\%), (GA-Cd 58.43\%,Pb $24.00 \%, \mathrm{Cu}-12.17 \%, \mathrm{Zn}-67.13 \% \mathrm{Cr}-18.02 \%$ ), while the percentage bioavailability at $15-30 \mathrm{~cm}$ depth were (GB- Cd 10.53\%, Pb 23.96\%, Cu-76.51\%, Zn-26.53\%, Cr 52.23\%), (GKi - Cd 44.44\%, Pb 23.19\%, Cu 5.54\% ,Zn 25.35\%,Cr-59.80\%), (TT-Cd 80.0\%, Pb 34.97\%, Cu31.79\%, Zn 5.19\%, Cr 50.24\%),(AM-Cd 26.67\%, Pb 39.74\%, Cu 13.88\%, Zn 2.45\%, Cr $25.90 \%$ ) and (GA-Cd 81.82\%, Pb 88.69\%, Cu-25.00\%, Zn 5.23\%, Cr 17.52\%). The high level of concentration of the heavy metals in the soils from the five experimental sites were slightly higher than from the control sites and higher than the recommended limits given by European Commission and World Health Organization.

Keywords: Auto-Repair Shops; Heavy Metals; Percentage Bioavailability; Soil 


\section{Open Access Journal of Waste Management \& Xenobiotics}

\section{Introduction}

Heavy metal is a general term used to describe a group of metals and metalloids with an atomic density greater than $5.0 \mathrm{~g} / \mathrm{cm}^{3}[1,2]$. These elements occur naturally in soils and rocks at various ranges of concentrations; they are also found in ground and surface water bodies and sediments [3]. Unchecked industrial and human activities have contributed significantly to elevated (pollution) levels of these metals, in surface and subsurface soils when compared to those contributed from geogenic or natural processes [4].

Soils may become contaminated by the accumulation of heavy metals and metalloids through emissions from the rapidly expanding industrial areas, mine tailings, disposal of high metal wastes, leaded gasoline and paints, land application of fertilizers, animal manures, sewage sludge, pesticides, wastewater irrigation, coal combustion residues, spillage of petrochemicals, and atmospheric deposition. Auto repair activities are one of the major sources of increase in heavy metals concentration in Nigeria [5]. These workshops are widely found as clusters of open land in the vicinity of urbanized areas offering services that generates various waste products [6,7]. The improper disposal of the waste products causes the gradual and eventual contamination of the soils and poses a serious health concern. It thus becomes imperative to continuously monitor the nature, volume, and harmful effect of the Current methods of waste disposal in order to ascertain their impact on the environment [8].

Their pollution of the environment even at low levels and the resulting long-term cumulative health effects are among the leading health concerns all over the word [2,3]. The concern is heightened by their persistence in the soil and their tendency to bio accumulates, move along the food chain and also poison soil microorganisms [9]. One of the major sources of increase in heavy metal concentration of the ecosystems in Nigeria is auto mechanic activities [5]. These auto mechanic workshops are found in clusters of open plots of land in the vicinity of urban towns and cities $[6,7]$.

Osuakwe, reported that the soil at the surroundings of auto repair dumpsites contain high level of heavy metals that could contaminate surface water, ground water, human and animals, through food chain which passes toxic and hazardous threats to both plant and animals in the environment [10]. Considering the large number of auto repair shops and their accompanying activities in Katsina North central, Nigeria necessitated the need to assess the level of soil contamination by heavy metals. This will ensure environmental sustainability and improved wellbeing of the people since it will shed more light on issues surrounding extent of contamination of soils. This study is aim at evaluating the auto repair shops soils for their heavy metal concentration.

\section{Materials and Methods}

\section{Description of Study Area}

Katsina is located on latitude $12^{\circ} 59^{\prime} \mathrm{N}$ and longitude $7^{\circ} 36^{\prime} \mathrm{E}$ and it's the capital city of Katsina state Nigeria. The city is the center of Agricultures, producing groundnuts, cotton, hides, millet and guinea corn. Soil is to be sampled from five (5) auto repair work shops in Katsina metropolis. The sampling sites was selected with consideration for large number of vehicles been repaired on daily basis, anthropogenic activities and compliance of the people in the study area. The selected sites are: Garejin Tsohuwar Tasha (TT), Albarkar MotorsGarage (AM), Garejin Abdulhadi (GA), Garejin Bebeji (GB) and Garejin Kofar Durbi (GK). One control soil (A) was collected from an unpolluted region located far away from the afore-mention mechanic sites. Each of the workshops occupy an estimated area of $150 \mathrm{X} 75 \mathrm{~m}$ with approximate total number of 60 cars per week been repaired.

\section{Sample Collection}

Soil samples from (5) selected auto repair workshops were collected which include Garejin Tsohuwar Tasha (TT), Albarkar Motors-Garage (AM), Garejin Abdulhadi (GA), Garejin Bebeji (GB) and Garejin Kofar Durbi (GK) and one control Area (C.A), each site was divided in to four (4) quadrants and the soil was collected from different depths $(0-15 \mathrm{~cm}$ and $15-30 \mathrm{~cm})$ using a clean soil auger. After collection, the soil samples were then mixed properly to get a representative composite of each quadrant [11]. The soil samples were placed in the labeled polythene bags and transported to the laboratory. All soil samples were subsequently air-dried to constant weight to avoid microbial degradation [12]. In order to obtain a homogenous sample, the soil was ground using a clean porcelain mortar and pestle and then sieved to obtain a finely grounded soil samples. Finally, the samples were stored in desiccators prior to analysis.

\section{Sample Preparation and Pre-Treatment}

Nine surface soil samples were collected randomly from each of the five selected auto repair workshop surroundings at a depth of $(0-15 \mathrm{~cm}$ and $15-30 \mathrm{~cm})$. One 


\section{Open Access Journal of Waste Management \& Xenobiotics}

control sample was also collected far away where neither car repairs, industrial nor commercial activities were been conducted. The samples were placed in labeled polythene bags and transported to the laboratory. All soil samples were subsequently air-dried to constant weight to avoid microbial degradation [2,12]. They were homogenized, made lump free by gently crushing repeatedly using an acid pre-washed mortar and pestle, and passed through a $2 \mathrm{~mm}$ plastic sieve prior to analysis.

\section{Determination of Heavy metals in the Soil}

One gram of the dried fine soil sample was weighed and transferred into an acid washed, round bottom flask containing $10 \mathrm{~cm} 3$ concentrated nitric acid. The mixture was slowly evaporated over a period of $1 \mathrm{~h}$ on a hot plate. Each of the solid residues obtained was digested with a 3:1 concentrated $\mathrm{HNO} 3$ and $\mathrm{HClO} 4$ mixture for $10 \mathrm{~m}$ at room temperature before heating on a hot plate. The digested mixture was placed on a hot plate and heated intermittently to ensure a steady temperature of $150^{\circ} \mathrm{C}$ over $5 \mathrm{~h}$ until the fumes of $\mathrm{HClO} 4$ were completely evaporated [2]. The mixture was allowed to cool to room temperature and then filtered using Whatman No.1 filter paper into a $50 \mathrm{~cm}^{3}$ volumetric flask and made up to the standard mark with de-ionized water after rinsing the reacting vessels, to recover any residual metal. The filtrate was then stored in pre-cleaned polyethylene storage bottles ready for analysis. Heavy metal concentrations were determined using an Atomic Absorption Spectrophotometer (AAS) at the National Research Institute for Chemical Technology (NARICT), Zaria. The instrument settings and operational conditions were in accordance with the manufacturer's specifications. The instrument was calibrated with analytical grade standard metal solutions $(1 \mathrm{mg} / \mathrm{dm} 3)$ in replicates.

\section{Contamination Factor}

$\mathrm{CF}$ is a quantification of the degree of contamination relative to either average Crustal composition of respective metal or to the measured background values from geologically similar and uncontaminated area [13]. It is expressed as: $\mathrm{CF}=\mathrm{Cm} / \mathrm{Bm}$ Where $\mathrm{Cm}$ is the mean concentration, while $\mathrm{Bm}$ is the background concentration of metal; either from literature (average Crustal abundance) or directly determined from a geologically similar area. CF will be defined according to four categories as follows:

\begin{tabular}{|c|c|}
\hline $\mathrm{CF}<1$ & Low contamination factor \\
\hline $1<\mathrm{CF}<3$ & Moderate contamination factor \\
\hline $3<\mathrm{CF}<6$ & Considerable contamination factor \\
\hline $6<\mathrm{CF}$ & Very high contamination factor \\
\hline
\end{tabular}

Table 1: CF Categories.

\section{Geo-Accumulation Index}

Geo accumulation was assessed based on the method described by Lokeshwari and Chandrappa. As Geol = In $(\mathrm{Cm} / 1.5 \times \mathrm{Bm})$. Where $\mathrm{Cm}$ is the mean concentration, while $\mathrm{Bm}$ is the background concentration of metal and 1.5 is a factor for possible variation in the background concentration due to lithologic differences.

\section{Pollution Load Index}

Furthermore, the severity of pollution of the soils, the pollution load index (PLI) defined and was evaluated with the expression: $\mathrm{PLI}=\left[n^{n} i\left(C_{f}\right)\right]^{1 / n}$ Where, $\mathrm{C}_{\mathrm{f}}$ is the contamination factor of each metal obtained by the ratio of concentration of each metal in soil to that of the metal in background soil; $\pi$ is the geometrical mean operator; $\mathrm{n}$ is the number of metals investigated in each sample [14].

\section{Results and Discussion}

\section{Determination of Heavy Metals in the Soils}

Heavy metals concentrations in the soil from the selected samples are higher in the auto repair shops than the control site. This could be explaining based on the work of Nwachuku, et al. who reported that engine oil and transmission fluids when discharged it increase the concentration of heavy metals in soils [7].

\section{Concentrations of Cadmium}

The Cadmium concentrations in the auto repair shops soils were above the standard limits $(3 \mathrm{mg} / \mathrm{kg}$ ) set by the world health organization (WHO) and European commission [15]. The high concentration of cadmium at the study areas could be attributed to lubricating oils, vehicle wheels dumping of PVC plastic cadmium batteries, and metal alloys used for hardening of engine parts.

The mean level of $\mathrm{Cd}$ in the workshop soils within the study areas ranged from $1.00-15.9 \mathrm{mg} / \mathrm{kg}$ at $0-15 \mathrm{~cm}$ and from $6.20-1.66 \mathrm{mg} / \mathrm{kg}$ at $15-30 \mathrm{~cm}, \mathrm{Cd}$ exhibited lower 
levels of contamination than those of the other metals studied. In a similar study the mean value obtained in soils of auto mechanic sites in Makurdi by Aloysius, et al. $(12.79-17.9 \mathrm{mg} / \mathrm{kg})$ and in Owerri municipal by Okoro, et al. (8.83- $18.67 \mathrm{mg} / \mathrm{kg}$ ) were lower than those reported here. The results were also higher than those reported in soils of abandoned mechanic workshops in Umuahia metropolis by Abii (19.4-25.6 mg/kg), Abbatoir dumpsite in Yauri, Kebbi state by Yahaya, et al. (0.14-7.00 mg/kg), and in municipal waste dumpsites in Benin City by Osaze, et al. $(0.009-0.016 \mathrm{mg} / \mathrm{kg})[2,16-19]$.

\section{Concentrations of Copper}

Copper had relatively high values ranging from 157 $\mathrm{mg} / \mathrm{kg}$ to $703.50 \mathrm{mg} / \mathrm{kg}$ at $0-15 \mathrm{~cm}$ and $1.90 \mathrm{mg} / \mathrm{kg}$ to $12.52 \mathrm{mg} / \mathrm{kg}$ at $15-30 \mathrm{~cm}$ depth. The exceptionally high value in Albarka $703.50 \mathrm{mg} / \mathrm{kg}$ could be attributed to automobile wastes containing electrical and electronic parts, such as copper wires, electrodes copper pipes and alloys from corroding vehicle scraps which have littered the vicinity for a long time [7]. These levels of $\mathrm{Cu}$ recorded in this study were similar to those recorded in soils of auto mechanic sites in Makurdi by Aloysius, et al. [2]. The levels are however lower than those reported in Owerri municipal by Okoro, et al. and in Akure by Oguntimehin, et al. but higher than the levels reported in automobile dumpsite soils in Agbor, Delta state by Osakwe and in the roads ide soils in Maiduguri by Uwah, et al. [10,16,20,21]. Copper concentration in the investigated workshops sites were found to be above the standard limits $(140 \mathrm{mg} / \mathrm{kg})$ set by European commission [15]. Also, the mean copper values in the control site were lower than those in the study areas. It's also above the standard set by the WHO.

\section{Concentrations of Chromium}

The mean concentration of chromium in the soils ranged from $39.25-295.30$ at $0-15 \mathrm{~cm}$ and $43.85-185.2$ at $15-30 \mathrm{~cm}$ which is above the WHO standard. Apparently, the mean value recorded at kofar Durbi study area appeared to be the lowest. According to Venkateswaran chromium is one of those heavy metals whose environmental conc. This is steadily increasing due to industrialization especially the metallurgical, chemical and tanning industries. Other sources through which chromium enters the environment are air and water erosion of rocks, liquid fuels and municipal waste although there is no risk of chromium contamination on a global scale, but local permeation of the metal to soil, water or the atmosphere might result in excessive amounts of this pollutants in biogeochemical circulation. As observed by Ghosh and Singh, the non biodegradability of chromium is responsible for its persistence in the environment once mixed in soil, it undergoes transformation into various mobile forms before ending into environmental sink ( $\mathrm{Cr}$ toxicity in the environment is very rare it still have some risk in human health since it can be accumulated on organ such as skin, lungs, and muscles [22-24].

\section{Concentrations of Lead}

Lead had relatively high values ranging from 436.60 $\mathrm{mg} / \mathrm{kg}$ to $18.15 \mathrm{mg} / \mathrm{kg}$ at $0-15 \mathrm{~cm}$ and $74.45 \mathrm{mg} / \mathrm{kg}$ to $8.32 \mathrm{mg} / \mathrm{kg}$ at $15-30 \mathrm{~cm}$. depth. Lead concentration in most of the study areas were generally above the standard limits $(300 \mathrm{mg} / \mathrm{kg}$ ) set by European commission (1986) and the WHO. This alarming high value in the study areas could easily be attributed to the activities in the auto mechanic clusters [15]. It was reported that $\mathrm{Pb}$ has the highest composition of heavy metals in waste auto oils [20]. It is thus possible that these high levels of $\mathrm{Pb}$ is elevated by the amount of waste oil, presence of automobile liquid emissions and expired motor batteries indiscriminately dumped by battery chargers and auto mechanics in the study area.

These levels of $\mathrm{Pb}$ recorded in this study are similar to those recorded in soils of auto mechanic sites in Akure by Oguntimehin and Ipinmoroti, on the other hand however, the ranges [20] 1.23-3.43 mg/kg, reported by Adewole in automobile workshops in Ile Ife, $25.85-38.83 \mathrm{mg} / \mathrm{kg}$ by Abii in Umuahia metropolis and $33.64-117.45 \mathrm{mg} / \mathrm{kg}$ by Atiemo in Accra are lower than those reported in this study. The, concentration ranges of 283-665 mg/kg reported by Aloysius in automobile workshops in Makurdi, 693-2917 mg/kg by Okoro in Owerri Municipal and $1162 \mathrm{mg} / \mathrm{kg}$ by Nwachukwu in auto mechanic village, Owerri were turned out to be higher than the range reported in this study $[2,5,7,16,17,25]$.

\section{Concentrations of Zinc}

The mean level of $\mathrm{Zn}$ in the auto mechanic soils within the study areas ranged from $80.75-460.95 \mathrm{mg} / \mathrm{kg}$ at the top soil and $23.30-74.15 \mathrm{mg} / \mathrm{kg}$ at the sub soil, this was considerably higher than the control site which recorded $59.49 \mathrm{mg} / \mathrm{kg}$ and $42.56 \mathrm{mg} / \mathrm{kg}$ at the top and sub soils respectively. Zinc is released into the soils of the study areas in a form of zinc oxide, which is an important component of vehicle paints it is also a component of automobile exhaust and part of additives to lubricating oils therefore the high concentration could be attributed to the activities which involve the use of these substances [26]. 
Levels of $\mathrm{Zn}$ recorded in this study were lower than values of $295-553 \mathrm{mg} / \mathrm{kg}$ reported in soils of auto mechanic sites in Makurdi by Aloysius and $824 \mathrm{mg} / \mathrm{kg}$ in auto mechanic village in Owerri by Nwachukwu ,but were higher than the values of $18.10-24.75 \mathrm{mg} / \mathrm{kg}$ in automobile workshops in Ile-Ife by AdewoleI and Uchegbu, it is also higher than the values(11.00-27.75 $\mathrm{mg} / \mathrm{kg}$ ) in automobile dumpsite soils at Agbor, Delta state by Osuakwe and $0.54-0.9 \mathrm{mg} / \mathrm{kg}$ in auto-repair workshops in Iwo by Ipeaiyeda [2,5,7,10,27]. Zinc concentration in most workshops soils were above the standard limits $(300 \mathrm{mg} / \mathrm{kg})$ set by European commission (1986) and the WHO [15].

\section{Percentage Bioavailability of Metals in the Five Selected Auto Repair Shop Soils}

Metal chemical speciation carried out by sequential extraction of the metals is essential in accessing the mobility and bioavailability of heavy metals in the workshop soils. The fractionating phases and the percentages of the bioavailable, residual and the nonresidual fractions across the sites for $\mathrm{Cd}, \mathrm{Pb}, \mathrm{Cu}, \mathrm{Zn}$ and $\mathrm{Cr}$.

\section{Percentage Bioavailability of Cadmium}

The concentration of cadmium in the extractable fractions and its percentage bioavailability in the workshop soils. Among the six geochemical fractions, the highest concentrations of $\mathrm{Cd}$ were recorded in the residual fractions at both depths $(0-15 \mathrm{~cm}$ and $15-30 \mathrm{~cm})$ which showed that they would be released into the environment only under very harsh conditions. Also the bioavailable percentages across the sites were relatively low and this may be related to the weak acidic soil property of the soils at the studied areas. Previous studies have reported that when the $\mathrm{pH}$ reached $7.5, \mathrm{Cd}$ will be hardly dissolvable. At a high $\mathrm{pH}$, water soluble $\mathrm{Cd}$ would enter the soil, existing mainly in state combining with clay mineral and oxide as well as residual fraction [28]. In addition, $\mathrm{Cd}$ ion adsorption will be greatly enhanced at a higher $\mathrm{pH}$ than at a lower $\mathrm{pH}$ due to hydrolysis $[29,30]$.

\section{Percentage Bioavailability of Copper}

The concentration of copper in the extractable fractions and its bioavailable percentages in the workshop soils. The highest concentrations of copper at both depths $(0-15 \mathrm{~cm}$ and $15-30 \mathrm{~cm})$ were recorded at the residual fraction but considerable high amounts of fractions were found in the organic phase, These indicates the effectiveness of organic matter as a scavenger of $\mathrm{Cu}$ in the soil. A number of studies on speciation of $\mathrm{Cu}$ have shown that it is mainly bound to the Oxidizable (organic bound) phase, occurring as organic complexed metal species. This is attributed to $\mathrm{Cu}$ having high affinity for humic substances which are a fraction of natural organic matter chemically active in complexing such metal [3133]. The high bioavailable percentage of copper across the sites indicates that $\mathrm{Cu}$ would be readily bioavailable to the environment for contamination and can cause environmental toxicity during mobility.

\section{Percentage Bioavailability of Chromium}

Relatively high concentrations of $\mathrm{Cr}$ in the extractable fractions at both depths were recorded at the residual fraction. The exchangeable phase accounted for the least fractions at both depths for most of the sites. The Fe-MnO fraction had considerable amounts of $\mathrm{Cr}$ across the sites. The bioavailable percentage of chromium across the sites was quite low, thus indicating that $\mathrm{Cr}$ would not be readily bioavailable to the environment for contamination and cannot cause environmental toxicity during mobility.

\section{Percentage Bioavailability of Lead}

The concentration of lead in the extractable fractions and its percentage bioavailability in the workshop soils. The highest concentrations of lead at the sites were recorded at the organic fraction and residual at $0-15 \mathrm{~cm}$ with GarejinTsohuwar Tasha having the highest concentration, while at 15-30 the highest concentration was recorded in the residual fraction at Garejin kofar Durbi study site. This finding was in agreement with what was reported by Kabata-Pendias who stated that there was a strong association of $\mathrm{Pb}$ with organic matter. It was thus found that, the oxide (organic bound) fractions scavenge $\mathrm{Pb}$ in natural and polluted soils which may eventually leads to its release into the environment $[34,35]$.

The bioavailable percentage of $\mathrm{Pb}$ appeared to be quite low compared to the other heavy metals. This could be due to its lack of soil mobility, as a result of its precipitation as insoluble phosphates, carbonates and hydroxides in water. Low levels of bio-available $\mathrm{Pb}$ or low mobility found in soils has been attributed to one or a combination of low native $\mathrm{Pb}$, very slow solubilization of $\mathrm{Pb}$ from soil minerals, strong adsorption of $\mathrm{Pb}$ on soil surfaces, or co-leaching of $\mathrm{Pb}$ with dissolved organic matter [36].

\section{Percentage Bioavailability of Zinc}

The concentration of Zinc in the extractable fractions and its percentage bioavailability in the selected auto repair shops soils. The lowest concentrations of zinc at 
both depths across the sites were recorded at the exchangeable phase Zinc in this fraction is the most mobile and readily available for biological uptake in the environment [37]. The exchangeable carbonate bound $\mathrm{Zn}$ was significantly higher than the exchangeable $\mathrm{Zn}$. thus Zinc extracted in this fraction would include weaklysorbed Zn species, particularly those retained on the soil surface by relatively weak electrostatic interactions and those that can be released by ion-exchange processes. It has been proposed that plant $\mathrm{Zn}$ uptake is largely from this fraction [38]. The concentration of $\mathrm{Zn}$ in the residual fraction was quite high. The percentage bio-available and non-residual phase of Zinc at both depths across the sites was quite high, while the residual phase which represented metals that are largely embedded in sedimentary matrix was relatively low.

\section{Assessment of Heavy Metals Contamination}

In order to have an idea about the levels of contamination of the soils of the auto mechanic workshop clusters, data obtained were compared with the background values. The background value of an element is the maximum level of the element in an environment beyond which the environment is said to be polluted with the element [39].

\section{Contamination Factor and Pollution Load Index}

The CFs for the five metals across the study sites and the control site at both depths are presented in Tables $2 \&$ 3. The trend is such that the highest CFs was observed in $\mathrm{Pb}$ and the least in $\mathrm{Cr}$. In general, the decreasing order of $\mathrm{CFs}$ was $\mathrm{Pb}>\mathrm{Cr}>\mathrm{Zn}>\mathrm{Cu}>\mathrm{Cd}$. On variation with depth $(0-$ $15 \mathrm{~cm}$ and $15-30 \mathrm{~cm}$ ) the CFs values generally decreased down the soil profile. The very high values of $\mathrm{Pb}$ could be due to influence of mechanic activities such as indiscriminate disposal of metal containing compounds engine oil, vehicle spare parts, and welding activities etc. The PLI which represents the number of times by which the metal content in the soil exceeds the average natural background concentration, and gives a summative indication of the overall level of heavy metal toxicity in a particular sample was also presented in Tables $2 \& 3$. Results showed that the highest PLI at both depths were recorded at Garejin Bebeji study site and the lowest PLI at the garejin tsohuwar tasha. All study sites had their PLI > 1 and the control site recording PLI $>1$. Based on the PLI grade standard by Harikumar, results showed pollution for the study sites and no pollution for the control site [40].

\begin{tabular}{|c|c|c|c|c|c|c|}
\hline Sites & CF(Zn) & CF(Cd) & CF(Cu) & CF(Pb) & CF(Cr) & PLI \\
\hline Garejin Bebeji & 4.85 & 4.58 & 3.38 & 21.73 & 3.02 & 5.48 \\
\hline Garejin Kofar Durbi & 0.93 & 4.25 & 4.15 & 5.15 & 0.44 & 2.06 \\
\hline Garejin T/ Tasha & 1.46 & 3.33 & 4.44 & 3.72 & 2.82 & 2.96 \\
\hline Albarka Motors & 0.85 & 5.92 & 15.63 & 4.92 & 2.14 & 3.83 \\
\hline Garejin Abdulhadi & 1.11 & 53 & 7.88 & 15.15 & 3.28 & 7.46 \\
\hline Control & 0.66 & 1.17 & 0.28 & 1.21 & 0.27 & 0.59 \\
\hline
\end{tabular}

Table 2: Contamination Factor and Pollution Load Index of the Five Selected Auto Repair Shops Soils at 0-15 cm Depth.

\begin{tabular}{|c|c|c|c|c|c|c|}
\hline Sites & CF(Zn) & CF(Cd) & CF(Cu) & CF(Pb) & CF(Cr) & PLI \\
\hline Garejin Bebeji & 0.78 & 0.75 & 0.16 & 0.91 & 2.06 & 0.7 \\
\hline Garejin Kofar Durbi & 0.27 & 1.77 & 0.17 & 1.13 & 0.52 & 0.54 \\
\hline GarejinT/Tasha & 0.73 & 1.75 & 0.26 & 0.56 & 0.49 & 0.62 \\
\hline Albarka Motors & 0.56 & 5.53 & 0.28 & 0.44 & 0.7 & 0.76 \\
\hline Garejin Abdulhadi & 0.25 & 0.67 & 0.04 & -0.42 & 0.5 & 0.57 \\
\hline Control & 0.35 & 1.72 & 0.37 & 0.33 & 0.47 & 0.51 \\
\hline \multicolumn{2}{|l}{ CF= Contamination Factor, PLI= Pollution Load Index } \\
\hline
\end{tabular}

Table 3: Contamination Factor and Pollution Load Index of the Five Selected Auto Repair Shops Soils at 15-30 cm Depth.

\section{Geo-accumulation Index (I-geo)}

The I-geo values for the five metals across the study sites and the control site at both depths were presented in
Tables 4 \& 5 . Zn had the highest I-geo values across the sites, while $\mathrm{Cu}$ appeared to have the least. The I-geo values of the study sites were higher than the control site. In general, the decreasing order of I-geo values were $\mathrm{Pb}>$ 
$\mathrm{Cr}>\mathrm{Cd}>\mathrm{Cu}>\mathrm{Zn}$. On variation with depth, the I-geo values generally decreased down the soil profile. The I-geo grade standard was developed by which showed the pollution status of the metals in the environment showed that study sites were moderately polluted with $\mathrm{Zn}$ and to a lower degree with $\mathrm{Cr}, \mathrm{Cu}, \mathrm{Cd}$ and $\mathrm{Pb}$, while it may be inferred that the control site was not polluted [4,41-44].

\begin{tabular}{|c|c|c|c|c|c|}
\hline Sites & Zinc & Cd & Cu & Pb & Cr \\
\hline Garejin Bebeji & 0.51 & 0.49 & 0.35 & 1.16 & 0.3 \\
\hline Garejin Kofar Durbi & -0.21 & 0.45 & 0.44 & 0.54 & -0.54 \\
\hline Garejin T/Tasha & -0.01 & 0.35 & 0.47 & 0.39 & 0.27 \\
\hline Albarka Motors & -0.25 & 0.6 & 1.02 & 0.52 & 0.15 \\
\hline Garejin Abdulhadi & -0.13 & 1.55 & 0.72 & 1 & 0.34 \\
\hline Control & -0.36 & -0.11 & -0.72 & -0.1 & -0.75 \\
\hline
\end{tabular}

Table 4: Geo-Accumulation Index of the Five Selected Auto Repair Shops Soils at 0-15 cm Depth.

\begin{tabular}{|c|c|c|c|c|c|}
\hline Sites & Zinc & Cd & Cu & Pb & Cr \\
\hline Garejin Bebeji & -0.28 & -0.3 & -0.98 & -0.22 & 0.14 \\
\hline Garejin Kofar Durbi & -0.75 & 0.07 & -0.95 & -0.12 & -0.46 \\
\hline Garejin T/ Tasha & -0.31 & 0.07 & -0.76 & -0.43 & -0.49 \\
\hline Albarka Motors & -0.43 & 0.57 & -0.73 & -0.54 & -0.33 \\
\hline Garejin Abdulhadi & -0.79 & -0.35 & -1.55 & BDL & -0.48 \\
\hline Control & -0.63 & 0.06 & -0.61 & -0.66 & -0.51 \\
\hline
\end{tabular}

Table 5: Geo-Accumulation Index of the Five Selected Auto Repair Shops at $15-30$ cm Depth.

\section{Conclusion}

The results obtained from this study had shown that soils sampled within the vicinity of auto repair shops at Garejin Kofar Durbi, Garejin Abdulhadi, Albarka motors, garejin tsohuwar tasha, and garejin bebeji were polluted. This was due to the activities within these areas that generate waste, due to oil spillage and indiscriminate disposal of metal scraps which contaminate the soils with heavy metals. The distribution patterns of metals in the six geochemical phases of the soil samples showed differences in both the study and control areas. The highest concentrations of metals were found in the residual fractions while the water soluble fractions had the least concentration. Also there was a high bioavailability associated with the heavy metals indicating that the metals under study pose environmental risk and are bioavailable for uptake by plants.

\section{Acknowledgement}

We are grateful to the entire staffs of the Laboratory of Department of Pure and Applied Chemistry, Ahmadu Bello University, Zaria, Nigeria, for providing technical assistance.

\section{References}

1. Duffus JH (2002) Heavy Metals-A Meaningless Term". Pure and Applied Chemistry 74(5): 793 -807.

2. Aloysius AP, Sha'Ato R, Offem JO (2013) Contributions of Automobile Mechanic Sites to Heavy Metals in Soil: A Case Study of North Bank Mechanic Village Makurdi, Benue State, Central Nigeria. Journal of Environmental Chemistry and Ecotoxicology 3(3): 2337-2347.

3. Hutton M, Symon C (1986) The Quantities of Cadmium, Lead, Mercury and arsenic entering The UK. Environment from human activities. Sci Total Environ 57: 129-150.

4. Dasaram B, Satyanarayanan M, Sudarshan V, Keshav KA (2010) Assessment of soil contamination in Patancheru industrial area, Hyderabad, Andhra Pradesh, India. Res J Environ Earth Sci 3(3): 214-220.

5. Adewole MB, Uchegbu LU (2010) Properties of soils and plants uptake within the vicinity of selected automobile workshops in Ile-Ife Southwestern 


\section{Open Access Journal of Waste Management \& Xenobiotics}

Nigeria. Ethiopian Journal of Environmental Studies and Management 3(3): 31- 35.

6. Nwachukwu AM, Feng H, Achilike K (2010) Integrated study for automobile waste management and environmentally friendly mechanic villages in the Imo River Basin, Nigeria. Afr J Environ Sci Tech 4(4): 234294.

7. Nwachukwu MA, Feng H, Alinnor J (2011) Trace metal Deposition in soil from Auto-mechanic village to urban residential areas in Owerri, Nigeria. Proceedings of Environmental Science 4: 310-322.

8. Lacatusu R (1998) Appraising levels of soil contamination and pollution with heavy metals. Env Sci 45: 453-567.

9. Udousoro II, Umoren IU, Asuquo EO (2010) Survey of some heavy metal concentrations in selected soils in South Eastern parts of Nigeria. World J Appl Sci Technol 2(2): 139.

10. Osuakwe SA (2010) Distribution of heavy metals in soils around Automobile dumpsites in Agbor and environs, Delta state, Nigeria. Journal of Chemical society of Nigeria 35(1): 53-60.

11. Rossel RV, Cattle SR, Ortega A, Fouad Y (2009) In situ measurements of soil colour, mineral composition and clay content by vis-NIR spectroscopy. Geoderma 150(3-4): 253-266.

12. Kakulu SE (1993) Biological monitoring of atmospheric trace metal deposition in North Eastern Nigeria. Environt Monit Assess 28(2): 137-143.

13. Tijani MN, Jinno K, Hiroshiro Y (2004) Environmental impact of heavy metal distribution in water and sediments of Ogunpa River, Ibadan area, Southwestern Nigeria. Journal of Mining and Geology 40(1): 73-83.

14. Agunbiade FO, Fawale AT (2009) Use of Siam weeds biomarker in assessing heavy metal contamination in traffic and solid waste polluted areas. Int J Environ Sci Tech 6(2): 267-278.

15. European Commission (EC) (1986) European Commission office for official publications of the European Communities, Luxembourg, Council Directive 66/27/EEC on the protection of environment and in particular of soil, when sewage sludge is used in agriculture.
16. Okoro AC, Chukwuma GO, Chukwuma EC, Nwachukwu PC, Ezeh KA (2013) Investigating the Effects Of Selected Heavy Metals On Topsoil At The Vicinities Of Two Automobile Mechanic Villages, Owerri Municipal, Nigeria. The International Journal of Engineering and Science 2(11): 19-26.

17. Abii TA (2012) Levels of heavy metals ( $\mathrm{Cr}, \mathrm{Pb}, \mathrm{Cd}$ ) available for plants within abandoned mechanic workshops in Umuahia Metropolis. Res J Chem Sci 2(2): 79-82.

18. Yahaya MI, Mohammad S, Abdullah BK (2009) Seasonal variations of heavy metals concentration in abattoir dumping site soil in Nigeria. Journal of Applied Sciences and Environmental Management 13(4): 9-13.

19. Osazee OJ, Obayagbona ON, Daniel EO (2013) Microbiology and Physicochemical analyses of top soils obtained from four municipal waste dumpsite in Benin City, Nigeria. International Journal of Microbiology and mycology 1(1): 23-30.

20. Oguntimehin I, Ipinmoroti KO (2008) Profile of heavy metals from automobile workshops in Akure, Nigeria. Journal of Environmental Science and Technology 1(7):19-26.

21. Uwah EI, John KO (2014) Heavy metal Levels in roadside soils of some major roads in Maiduguri, Nigeria. Journal of Applied Chemistry 6(6): 74-78.

22. Bartlett RJ (1988) Mobility and bioavailability of Chromium in soils. Adv Environ Sci Technol 20: 267304.

23. Bartlett RJ, James B (1983) Behavior of Chromium in soils: VII, Adsorption and Reduction of Hexavalent form. J Environ Qual 12(2): 177-181.

24. Reyes-Gutierrez LR, Romero-Guzman ET, CabralPreito A, Rodriguez-Castillo R (2007) Characterization of chromium in contaminated soil studied by SEM, EDS, XRD, and Mossbauer spectroscopy. J Miner Mater characterization Eng 7(1): 59-70.

25. Atiemo M, Ofosu FG, Aboh IJK, Oppon OC (2012) Levels and sources of heavy metal contamination in road dust in selected major highways of Accra, Ghana. Sampson X-Ray Spectrometry 41(2): 105-110. 


\section{Open Access Journal of Waste Management \& Xenobiotics}

26. Adriano DC (2001) Trace elements in the terrestrial environment, Springer-Verlag, $2^{\text {nd }}(E d n)$, NY, pp: 324.

27. Ipeaiyeda AR, Modupe D, Yewande A (2008) Heavy metals contamination of Topsoil and Dispersion in the vicinities of reclaimed Auto-Repair workshops in Iwo, Nigeria. Research Journal of Applied Sciences 2(11): 1106-1115.

28. Dai A (2006) Precipitation characteristics in eighteen coupled climate models. Journal of Climate 19(18): 4605-4630.

29. Ali MA, Dzombak DA (1996) Effects of simple organic acids on sorption of $\mathrm{Cu}^{2+}$ and $\mathrm{Ca}^{2+}$ on goethite. Geochemical Cosmotic Acta 60(2): 291-304.

30. Fijalkowski K, Kacprak M, Grobelak A, Placek A (2012) The influence of selected soil parameters on the mobility of heavy metals in soils. Inzynieria I Ochrona Srodowiska 15(1): 81-92.

31. Pardo R, Barado EE, Perez L, Vega M (1990) Determination and speciation of copper and lead in sediments of Mediterranean river Riverteen, Catalonia, Spain. Water Resource 22: 449-455.

32. Fytianos K, Lourantou A (2004) Heavy metal distribution in sediment samples collected at lakes Volvi and Koronia N, Greece. Environmen Int 30(1): 11-17.

33. Pempkowiak J, Sikora A, Biernacka E (1999) Speciation of heavy metals in marine sediments versus their bioaccumulation by nussels. Chemosphere 39(2): 313-321.

34. Kabata-Pendias A (1992) Trace metals in soils in Poland-occurrence and behaviour. Soil Sci 140: 53-70.

35. Xian X, Shokohifard GI (1989) Effect of pH on chemical forms and plant availability of cadmium, zinc, and lead in polluted soils. Water, Air and Soil Pollution 45(3-4): 265-273.
36. Rieuwerts JS, Searle P, Buck R (2006) Bioaccessible arsenic in the home environment in Southwest England. Science of the Total Environment 371(1-3): 89-98.

37. Ghosh M, Singh SP (2005) Comparative uptake and phytoextraction study of soil induced chromium by accumulator and high biomass weed species. Appl Ecol Environ Res 3(2): 67-79.

38. Shuman LM (1991) The effect of soil properties on zinc adsorption by soils. Soil Science Society of America Proceedings 39(3): 454-458.

39. Puyate YT, Rim-Rukeh A, Awatefe JK (2007) Metal pollution assessment and particle size distribution of bottom sediment of Orogundo River, Agbor, Delta State, Nigeria. Journal of Applied Science Research 3(12): 2056-2061.

40. Kumar HK, Pasupuleti V, Jayaraman M, Abhyuday V, Modi K (2009) Role of Thyroid Dopler in Differential Diagnosis of Thyrotoxicosis. Endocrine Practice 15(1): 6-9.

41. Muller G (1969) Index of geo-accumulation in sediments of the Rhine River. Geo J 2(3): 108-118.

42. Adepoju MO, Adekoya JA (2008) Distribution and assessment of heavy metals in sediments of the river orle, south-western Nigeria. J Sustainable Dev Environ Protection 2(1): 78-97.

43. Awolofu OR (2005) A survey of trace metals in vegetation, soil, and lower animals along some selected major roads in metropolitan city of Lagos. Environ Monit Assess 105(1-3): 431-447.

44. Lokeshwan H, Chandrappa GT (2006) Impact of heavy metal contamination of Bellandur Lake on soil and Cultivated vegetation. Curr Sci 91(5): 622-627. 